\title{
Social Cognitive Theory Test: Role of Anxiety in getting Professional Sanction in Professionalism and Auditor Independence
}

\author{
FRANCISCA RENI RETNO ANGGRAINI* \\ Universitas Sanata Dharma
}

\author{
ZAKI BARIDWAN \\ SUWARDJONO \\ HARDO BASUKI \\ Universitas Gadjah Mada
}

\begin{abstract}
Scandals in auditing have deteriorated the credibility of the accounting profession. The low law enforcement and concentrated ownership structure in Indonesia (La Porta et al., 1999; Siregar, 2006) has led to lower auditor independence. This study uses social cognitive theory in modeling. Based on social cognitive theory, law enforcement influences auditor's concern to professional sanction. Then, the concern to professional sanction is cognitive which influence auditor's independence. The objectives of this research are to examine the effect of work context to the level of auditor's concern to professional sanction, the role of auditor's concern to professional sanction to his or her professionalism and independence. Based on scenario-based surveys in Jakarta, Surabaya, Semarang, Denpasar, Yogyakarta, we received 186 usable questionnaires (83 questionnaires from auditors working in non-big four accounting firms and 103 questionnaires from auditors who work in big four firms). This study uses multiple regression analysis and independent sample test. This study found that work context did not influence the level of auditor's concern to professional sanction but auditor's concern to professional sanction influences his or her independence to the audited. Finally, this research provides evidence that professionalism and concern to professional sanction have substitution effect to auditor's independence.
\end{abstract}

Keywords: Concern to Professional Sanction, Auditor's Independence, Work Context, Social Cognitive Theory

Intisari: Skandal dalam audit telah memburuk kredibilitas profesi akuntansi. Rendahnya penegakan hukum dan struktur kepemilikan yang terkonsentrasi di Indonesia (La Porta et al, 1999; Siregar, 2006) telah menyebabkan independensi auditor yang lebih rendah. Penelitian ini menggunakan teori kognitif sosial dalam pemodelan. Berdasarkan teori kognitif sosial, penegakan hukum mempengaruhi kepedulian auditor terhadap sanksi profesional. Kemudian, perhatian terhadap sanksi profesional adalah kognitif yang memengaruhi independensi auditor. Tujuan dari penelitian ini adalah untuk menguji pengaruh konteks kerja terhadap tingkat 
perhatian auditor terhadap sanksi profesional, peran perhatian auditor terhadap sanksi profesional terhadap profesionalisme dan kemandiriannya. Berdasarkan survei berbasis skenario di Jakarta, Surabaya, Semarang, Denpasar, Yogyakarta, kami menerima 186 kuesioner yang memenuhi syarat (83 kuesioner dari auditor yang bekerja di kantor akuntan non big 4 dan 103 kuesioner dari auditor yang bekerja di 4 perusahaan besar). Penelitian ini menggunakan analisis regresi berganda dan uji sampel independen. Studi ini menemukan bahwa konteks kerja tidak mempengaruhi tingkat perhatian auditor terhadap sanksi profesional, tetapi perhatian auditor terhadap sanksi profesional mempengaruhi independensinya terhadap auditor yang diaudit. Akhirnya, penelitian ini memberikan bukti bahwa profesionalisme dan perhatian terhadap sanksi profesional memiliki efek substitusi terhadap independensi auditor.

Kata Kunci: Kekhawatiran terhadap Sanksi Profesional, Independensi Auditor, Konteks Kerja, Teori Kognitif Sosial

\section{Introduction}

The emerging scandals between an auditor and their audited clients cause the decrease of public trust towards the auditor's professionalism. The scandals are unavoidable due to the auditor's position, cause oneself unable to act professionally. In the guideline of National Committee of Governance (KNKG, 2006) was said that the chosen auditor was appointed by RUPS (General Meeting of the Shareholders) through the Board of Commissioners. In reality, it was found many RUPS gave their authority to the Board of Directors. In such condition, the Board of Directors has a more powerful position to control the audit of a financial statement of companies. In the auditor's position, business continuity is also considered when they accept the auditing assignment. This may cause the auditor unable to be professional, hence, in ones' turn, can't act independently. Enron case shows evidence that auditor is helpless against the audited when the audited can give a significant income for him (Zeff, 2003).

Incidences of audit scandals cause reactions from IAI (Institute of Indonesia Chartered Accountants), IAPI (Indonesian Public Accountant Institute) and the government to manage the work of accountants and auditor. To increase auditor's professionalism, IAI and IAPI had made a policy to regulate the process of accountancy education in Indonesia (Akuntan Indonesia, 2012: 8). This policy was 
done to increase the knowledge and skills of an auditor. Other than that, the Indonesian government has ratified UU Number 5 the Year 2011 about Public Accountant and Government Ordinance Number 84 the year 2012 about Public Accountant Profession Committee. One of the job desks of Public Accountant Profession Committee is to give considerations towards the empowerment, coaching and supervision policy of public accountant and KAP. This was intended to increase the quality of the financial report, sound system, and tax necessities.

IAI dan IAPI policy and ratification of two rules above was expected to increase the quality of auditor work and at last, will increase public trust towards Indonesian capital market. On the other hand, those two rules increase the risk for auditor in doing his job. This may cause anxiety for an auditor that he might get professional sanction when they are wrong in giving audit opinion. Auditor's worries of getting professional sanction enable an auditor to be careful in giving opinions. This will increase auditor's independence. In consequence, worries of getting professional sanction are not only affected by whether there is or there is no regulation that controls, but also whether those rules are made well or not.

This experiment aims to test whether getting professional sanction has a significant role in the increase of auditor's performance. This experiment is based on the theory of social cognitive theory. The social cognitive theory states that in making an individual decision there are three elements correlated to each other, they are behavior, cognitive and environment. The cognitive development of a person is significantly affected by the environment where that person is making a decision. Anggraini et al. (2013) found that auditor's professional development is affected by the auditor's workplace. This means that the work environment affects cognitive, by the professionalism showed. Other than that, work environment also affects behavior, which is indicated by independence. This experiment identifies the law environment as a factor that was suspected to affect cognitive development and someone's' behavior. According to social cognitive theory, the worries of getting professional sanction is a result of a cognitive process that was formed from individual experience in perceiving the law environment. Auditor's experience in law environment will 
inflict perception and appraisal to the risk of struck by professional sanction. This will create a level of anxiety of being incurred by professional sanction.

This experiment shows empirical evidence that first; there is no anxiety difference against being incurred by professional sanction between auditors that work in KAP big 4 or non-big 4. Secondly, there is an influence of worries getting professional sanction on auditor's independence. This supports the cognitive, social theory that cognitive impacts behavior. Thirdly, there's an anxiety moderation effect of getting professional sanction on relationships between professionalism and auditor's independence. However, this moderation effect is in contrary to the hypothesis because moderation's effect characteristic is negative. This means that professionalism and anxiety of getting professional sanction substitutes in enhancing the independence of the auditor. If the auditor is less professional but has a high professional sanction level of concern, then independence will be high.

The results of this study are expected to contribute to the government and the Public Accounting Profession Committee on the role of law enforcement (law enforcement) in improving the performance of auditors and ultimately the quality of financial statements. The results of this study are expected to provide evidence for the implementation role of the rules that are effective in changing the behavior of auditors towards the better.

\section{Theoretical Framework and Hypothesis Development}

\subsection{Social Cognitive Theory}

Social cognitive theory introduced by Bandura in 1986 is the development of social learning theory (social learning theory) which was also written by him in 1977 (Bandura, 2001). According to social cognitive theory, three aspects affect each other in the decision-making process of individuals, namely cognitive (and other personal factors), environment, and behavior. Independent behavior of the auditor is a manifestation of the cognitive processes that auditors in information processing. This information not only from experience itself but also involves the social context of the auditor's interaction and experience with others in the past. Information derived from 
the social context and the experience of others is called social information (Salancik and Pfeffer, 1978). Processing of social information related to learning that someone has done during his interaction in a given environment. Pop-up of the processing of this information will be used to form the self-regulation system will further establish themselves. Pop-up of social information processing is done in interaction with the environment in which he works will appear on the behavior exhibited by the individual. According to Bandura (2001), self-regulation dealing with the capacity to coordinate the process of cognitive, affective and behavioral to achieve established goals. This self-regulation would form self-efficacy that can be used as a guideline for a person to be able to act upon the target set. Concerns of a professional auditor's being sanctioned pop-ups from cognitive processes in the face of the risk of getting professional sanctions. The level of concern will depend on his own experience or the experience of others when they are wrong in giving opinions. Concerns of sanctioned professional auditor will affect the behavior shown by the independence of the auditor to be audited. Law characteristics and its implementation will also affect the performance of auditors. Cross-country research shows that the big four auditors from accounting firm do not necessarily indicate that audit quality is better than the non-big four accounting firm (Favere-Marches, 2000; Khurara and Raman, 2004; Francis and Wang, 2008; and Michas, 2011). These studies show that the level of investor protection will affect the behavior of auditors. Francis and Wang (2008) found that the level of investor protection in a country has a strong influence on the performance of KAP big 4. KAP big four operating in countries with weak investor protection level indicate that audit quality is not better than non-big KAP 4. Weak investor protection level causes audited dare to suppress auditor to fulfill her desire (Fan and Wong, 2005).

On the other hand, the auditor is also afraid to act independently because of the risk of low litigation he faces (Francis et al., 2002; Francis and Wang, 2008). Auditor in Indonesia may also tend not to act independently because, according to La Porta et al., (2006), Indonesia is among countries with the characteristics of a weak level of investor protection. On the other hand, companies in Indonesia have the characteristics 
of concentrated ownership (Siregar, 2006). Concentrated ownership resulted in the expropriation of the majority shareholder on a minority shareholder. The dominance of the majority shareholder in the company is also demonstrated by the lack of a clear separation between the manager and majority shareholder since the majority shareholders also held the manager. In the company whose ownership is concentrated in families, managers or directors and commissioners are not independent are generally derived or still have family ties with the majority shareholder. In these conditions, any independent commissioner may also not work optimally because of the dominance of the majority shareholders is very strong. Even based on a search of the general meeting of shareholders (AGM), the authors found that the AGM on several companies has delegated the authority to the directors to appoint, suspend and provide compensation to the auditors who audited the financial statements of the company. In these situations, the auditor will have a fragile position when auditing the company so that the auditor can not act independently and ultimately opinions given are not objective.

Based on a psychological perspective, the legal environment will affect the assessment of a person to the risk of sanctions. Clarkson et al. (2002) say that when a person sees the adverse effects of the action, then he will be careful in doing the same action in the future. This means a negative impact of an action taken will reduce cognitive biases that occur in the processing of information by the auditor. The higher the risk, the higher the professional sanction and the concerns. These concerns will further increase the independence of the auditor.

\subsection{Concerns of getting Professional Sanctions}

Any professional organizations have rules and standards to regulate the conduct and work of its members. Likewise, the auditor in the audit performance must comply with the norms and standards established by the organization auditing public accounting profession (in Indonesia is IAPI) and the rules and norms applied in which he worked. The Indonesian government has also approved Law (UU) No. 5/2011 about Public Accountant.UU Is expected to make the highest legal basis to regulate 
and protect the profession of private auditors and is expected to boost confidence in the Indonesian audit profession, which in turn will develop the Indonesian capital market.

If the valid rules can be run, the auditor who violates the rules will be sanctioned either by a professional organization or government. According to Law No. 5 of 2011, the threat of punishment that can be imposed on a public accountant or auditor is not limited to the imposition of sanctions by the temporary suspension or revocation of a license to practice, but the government also has the authority to impose criminal threats to the auditor who severely violate professional ethics.

Melumad and Thoman (1990) found that the threat of litigation allows the auditor decides to work and make their reports correctly about his findings to reduce the prospect of future losses. High threat of litigation caused the auditor to seek a way to reduce this risk by improving the quality and audit planning, and audit costs increase, more often issued opinions with modifications and more selective in choosing clients (Khrishnan and Khrishnan, 1997). Farmer et al. (1987) found that the threat of litigation resulted in the auditor to be more cautious in examining the financial statements.

An environment with a high threat of litigation resulted in auditors to be more ethical than the environment with a lower threat of litigation. Countries that have a code of professional conduct will either show the auditor have higher sensitivity levels to ethical dilemmas (Douglas et al., 2001; Dreike and Moeckel, 1995; Claypool et al., 1990 cited by Jones et al., 2003). The existence of a code of conduct made ethical ambiguity reduced and will assist the auditor in recognizing the ethical issues and help distinguish actions that are ethical and unethical. Krishnan and Krishnan (1997) suggest that the risk of litigation is an essential factor to be considered in providing the auditor's opinion on the financial statements of his client.

The critical role of regulation in enhancing the auditor's independence depends on how strong the law enforcement that runs in a country. Effective law enforcement will cause concern to the auditor about the possibility that he would be exposed to litigation if he does not perform audits properly. According to social cognitive theory, 
a person will behave as others do when the behavior of others that provide benefits (give positive impact) and will not do what others do when their actions cause harm (to give negative impact). Therefore, when a lot of other auditors who gets punished for his mistake in giving specific audit opinion the auditor will be cautious in carrying out his duties.

In this study, concerns about litigation are defined as the perception of the auditor regarding the possible risks he would receive when he does not perform audits following auditing standards and regulations. This study uses two items of questions to measure this construct, the first related to whether the applicable rules will be taken into consideration for the audit process to be done and second, whether the auditor's experience earlier that violate rules and sanctions will make him more careful in carrying out his work

\subsection{Concerns of getting Professional Sanctions and Employment Context}

According to social cognitive theory, the environment will affect the formation of a person's cognitive. Results of research Anggraini et al. (2013) showed that the effect on the employment professionalism context and auditor's independence. Auditors working in KAP big 4 have lower professionalism and independence than the non-big KAP 4. The results of this study support the idea Gendron et al. (2006) and Suddaby et al. (2009). The results of the above studies are in alignment with the arguments of the social cognitive theory that the environment will affect the cognitive and behavior. According to social cognitive theory, personal experience and others will affect the formation of self-efficacy. This self-efficacy will affect self-regulation. Lower professionalism and independence in big four auditor at KAP compared to an auditor in non-big four can be caused due to the big 4's are bolder to face professional sanctions risk compared with non-big four auditor at KAP. This is because the auditor at KAP big four may perceive he would not be sanctioned because KAP big four professional has a higher power to avoid those sanctions. Research conducted by Francis et al. (2002), Khurara and Raman (2004), Francis and Wang (2008), and Michas (2011) showed that the level of protection of investors in one country affects 
the performance of auditor at KAP big 4. Jeong and Rho (2004), using sample companies in Korea, found that the quality of audit (the proxy for discretionary accruals) between KAP big 4 and non-big 4 is no different. Hwang and Chang (2010) found that the litigation environment has a significant influence on the auditor's decision.

Indonesia is among countries with a weak level of investor protection and also has the characteristics of weak law enforcement as well (La Porta et al., 2006). Besides, Moore et al. (2006) also say that the group with more power can influence the regulator in making the rules. In Indonesia, the professional organizations that exist, primarily dominated by people or groups who have a strong influence because they can fund the activities carried out by the professional organizations. The same thing happens in IICPA, members of organizations that have strong influence auditors are derived from all big KAPs, including big 4. It can be understood as the KAP big 4 have the number of auditors and have a lot of financial resources. With the political power of the firm where the auditors work, might cause auditors to be more daring not to obey the rules. When the auditor perceived that the firm where he works could protect themselves from the imposition of sanctions as a result of negligence in carrying out the audits properly, then professional sanction concerns will be low. Auditor with the big four would likely have greater confidence that he was able to avoid sanctions, so the professional sanctions concerns will also be low.

Therefore, the working context alleged the effect on the magnitude of professional sanction concerns when auditors do not carry out audits following the standard. Auditor with the big four would feel more courageous to face this risk compared auditors working in KAP non-big four because they think has a greater ability to resolve ethical dilemmas faced. Thus, fears of an auditor at KAP non-big four professional sanctions greater than the auditor at KAP big 4. Therefore, the alternative hypothesis can be formulated as follows:

H1. Auditors working in KAP the big four have lower professional sanction concerns than the auditors working in non-big four accounting firm. 


\subsection{Concerns of getting Professional Sanctions, professionalism, and independence of} the Auditor

Research on audit quality between KAP Big 4 and non-Big 4 was carried out after the Enron scandal, showing that the big four auditors in KAP become more cautious in carrying out audit services (e.g., Fargher et al., 2001). This is done to restore the reputation of KAP big four after Andersen destroyed this reputation in the Enron scandal. $\mathrm{Lu}$ (2006) found that the replacement does not degrade the auditor independence and audit quality in the period after the Enron scandal emerged. Rama and Read (2006) also found that the advent of SOX Acts 2002 lead auditor increasingly cautious in providing services, especially when he got the first task after replacing the old auditor.

The results of the above studies show that after the audit scandals revealed, the perceptions of risks to be borne out when the auditor was wrong in giving an opinion, were greater. When audited was convicted of fraud and the auditors did not know it, for the auditor, in addition to the sanctions that will be accepted, his reputation would be ruined. The higher the risk of sanctions resulted in the firm being cautious in conducting audits.

Implementation of the law enforcement is set to be influential in determining the level of risk of sanctions for violations of those rules. If the auditor ever violated and got punished, or a lot of people see those who break the rules and got punished, then auditors would be more careful in the work. As quoted by Jones et al. (2003), studies by Douglas et al. (2001), Dreike and Moeckel (1995), Claypool et al. (1990) provide evidence that a person's behavior in an environment with a high threat of litigation would act more ethically than the behavior of people who are in an environment with a low threat of litigation. People who are in an environment with a high threat of litigation is more sensitive to ethical dilemmas that people who are in an environment with a low threat of litigation. The results of these studies indicate that the perception of the risks that may be encountered, can predispose a person to be more sensitive to the ethical dilemma and then they would be careful in acting, especially in actions that may be a risk to his career and reputation. This means the regulations made will have 
an impact on the behavior of a person if he has confidence that if he violates, it will be likely that he gets sanctioned. Conversely, if he has confidence that if he violates but getting sanctioned, then he is likely to violate.

The social cognitive theory explains that self-experience and others' experience will affect the cognitive formed. Cognitive is used to form the self-regulation and selfregulation will further establish self-efficacy. Self-efficacy will be used as a guide and tool control in action. The success obtained either by oneself or others will strengthen self-efficacy and failure will weaken self-efficacy. Failure to resolve ethical dilemmas in the past will result in a person to avoid the same problem in the future, and if he had to face the same problem, then he should avoid settlement in which, the past failed. Auditor's professional sanction future concerns results in the avoidance of these problems.

Clarkson et al. (2002) found that cognitive bias can be reduced if one can sense that as a result of the actions taken can have negative effects on themselves. Grant et al. (1996), by conducting experimental research, finding that the regulations made by professional organizations have an essential role in improving audit quality and is increasingly becoming a more significant role when there are effective sanctions mechanism. Anggraini et al. (2013) research results, showed that the auditor's professionalism, influence his independence against the audited. Professionalism is the result of a process of cognitive development experienced by auditors in a particular work environment. The same is professional sanctioned concerns. The higher professional sanction concerns from professional organizations will also cause the auditor to be more careful in doing the job. This means that the higher the auditor's concerns will be sanctioned professionally, then he will be more independent of the audited. Therefore, the hypothesis is:

H2. Professional auditor sanction concerns give a positive effect on the independence of the audited.

Results of research Anggraini et al. (2013) showed that employment context affects professionalism and auditor's independence. However, the context does not 
moderate the relationship between work professionalism and independence. I suspect that professional sanction concerns and professionalism are mutually reinforcing to increase the independence of auditors. The higher the professional sanction concerns and the higher professionalism of the auditor, the more capable the auditor to face ethical dilemmas when acting independently towards the audited. Therefore, the hypothesis is:

H3. The positive influence on the professionalism of auditor independence will be stronger when the professional sanction concerns are higher.

\section{Research Methods}

\subsection{Subject Research}

The research subjects (participants) in this study is the auditor who works in the big 4 and non-big 4 KAP. The sampling method used was purposive sampling because KAP attended based on the address can be found by investigators. Questionnaires were administered to the auditor with the position of junior partner to the auditor at KAPs in Jakarta, Surabaya, Semarang, Denpasar, and Yogyakarta.

\section{Methods for Data Collection}

This research was conducted in 2010-2011 with a survey method based scenarios. In the scenario, participants (in this case the auditor) faced with the problem to follow the wishes of their clients, simultaneously; he was faced with the rules governing the work and if it does not comply will be sanctioned by the freezing of license to practice. The subject is asked to act as if they are a partner in an accounting firm and had to decide to meet the wishes of audited or not.

By using the auditor subject, research on decision making by professionals will be closer to the actual conditions in practice so that study is expected to capture the behavior of professionals in addressing the real ethical dilemmas. This is due to decisions taken by the professional will tend to be based on their experiences during the auditing. 
The scenario used is a case that shows the differences between the auditor and the audited assessment of the reserve estimation has obsolete inventory. The internal auditor has approved the estimates made by the company because they assume that the estimates made are not significantly different from the estimates made in the past year.

2. Operational Definition of Variables Research

a. The level of independence (INDPi)

Measurement of this variable is the same as that of the Anggraini et al. (2013) is by using instruments made by Rahim (1983), known as ROCI-II (The Rahim Organizational Conflict Inventory-II) with minor modifications to suit the given scenario. This study only uses the items to measure the types of strategies to dominate the course (i.e., item numbers 10, 11, 24, 27) for the auditor's independence more related to the selection of strategies dominate. Scores of independences measure the total value score of four questions. Total score of independence is after this referred ROCI-II scores dominate strategy.

b. Work context (BIG4)

As performed by Anggraini et al. (2013), work context dummy variables measure where a subject worked. Subjects will be assigned a value of 0 if he works at KAP non-big four and if he works at KAP big four given numbers 1 .

c. Professional sanction concerns (SPi)

This variable was measured by using the following two questions:

1) Government rule in the form of freezing permits for the practice of public accounting will be considered in the audit process that I do.2) Because it is based on previous experience, a lot of the Firm or Public Accountant license suspended its audit practice, and then I would be cautious in giving an opinion. 
Professional sanction concerns score, measure the total score of the two questions. Total professionalism score is named after scores of professional sanctions.

\section{d. Professionalism (PROFSi)}

As performed by Anggraini et al. (2013), professionalism auditor measured using the measurement as used by Liu et al. (2003). They use the measurement requirements of the professional role of Miner (1993). Four dimensions make up professionalism: (1) improving the knowledge, (2) to act independently, (3) recognizes the status, (4) willing to help, and (5) demonstrate a professional commitment. Professionalism scores measured by the total score of 21 questions. Total professionalism score is called after Miner score.

e. Control variable

As performed by Anggraini et al. (2013), this study included three control variables, namely:

1) Auditor's Position (Jabi) Subjects were divided into four levels starting from a partner, manager, senior auditors, and junior auditors. Assessment is based on ranking positions. Partners who occupy the highest positions rated four until the junior auditor lowest positions rated 1 .

2) Gender (GNDi)

This study measures the gender variable by giving a value of 1 in women and 0 on the male subjects. 3) Experience (PGLM1i, PGLM2i, and Umi)

Experience is measured in three ways. Namely, the length of respondents worked in KAP (PGLM1i) and the length of respondents' work as an auditor (PGLM2i).

4) Context Working (Bigi)

The employment context is dummy variables if auditors working in KAP big four are numbered 1 , while if it is not assigned a value of 0 . 


\subsection{Research Model and Testing Method}

The research model and its testing method are as follows:

Hypothesis testing is one done with different Independent test samples (Independent Sample Test)

Hypothesis 4 is supported if the average SPi, BIG 4 <average SPi, NON-BIG 4.

Information:

$\mathrm{SPi}, \mathrm{BIG} 4$ = Auditors' professional sanction fears of working in

KAP big 4

SPi, NON-BIG 4 = Auditors' professional sanction fears of working inKAP non-big four

a. Testing hypotheses 2 and 3 performed with Multiple Regression Analysis Model testing:

$\mathrm{INDP}_{\mathrm{i}}=\beta_{0}+\beta_{1} \mathrm{SP}_{\mathrm{i}}+\beta_{4} \mathrm{PROFS}_{\mathrm{i}} * \mathrm{SP}_{\mathrm{i}}+$ Control Variable $+\varepsilon_{\mathrm{i}}$

Keterangan:

$\mathrm{INDP}_{\mathrm{i}}=$ Auditor Independence Level $i$

$\mathrm{PROFS}_{\mathrm{i}}=$ Auditor Professionalism Level $i$

$\mathrm{SP}_{\mathrm{i}}=$ Professional sanction fears level

Control Variabel include:

$\mathrm{JAB}_{\mathrm{i}}=$ Auditor's position

$\mathrm{GND}_{\mathrm{i}}=$ Gender

PGLM $1_{i}=$ Experience in KAP now

PGLM2 $2_{\mathrm{i}}=$ Experience as an auditor

$\mathrm{UM}_{\mathrm{i}}=$ Auditor's age 


\section{Results}

\subsection{Descriptive Statistics}

This research uses respondent auditors working in KAP Big 4, and non-big four are located in Jakarta, Surabaya, Semarang, Yogyakarta, and Denpasar. Especially for auditors working in KAP big four only taken two big four accounting firm in Jakarta. Distribution of questionnaires began from January 2010 to July 2011. Questionnaires were distributed as many as 350 pieces and questionnaires were returned and completed in full, a total of 207 pieces. This shows response rates were high at $59.14 \%$. The questionnaire comprises a total of 207 pieces of 95 respondents from non-big four accounting firm and 112 respondents from big 4 KAP. Descriptive statistics for each of the variables tested are presented in Table 1.

Table 1

Descriptive Statistic

\begin{tabular}{lcccccccc}
\hline & \multicolumn{2}{c}{ Mean } & \multicolumn{2}{c}{ Minimum } & Maximum & \multicolumn{2}{c}{$\begin{array}{c}\text { Standard } \\
\text { Deviation }\end{array}$} \\
\cline { 2 - 9 } & Big 4 & $\begin{array}{l}\text { Non- } \\
\text { big 4 }\end{array}$ & Big 4 & $\begin{array}{l}\text { Non- } \\
\text { big 4 }\end{array}$ & Big 4 & $\begin{array}{c}\text { Non- } \\
\text { big 4 }\end{array}$ & $\begin{array}{c}\text { Big } \\
4\end{array}$ & $\begin{array}{c}\text { Non- } \\
\text { big } \\
4\end{array}$ \\
\hline $\begin{array}{l}\text { Professional sanction } \\
\text { concerns (SP }\end{array}$ & 7,99 & 8,29 & 3,00 & 2,00 & 10,00 & 10,00 & 1,50 & 1,38 \\
\hline $\begin{array}{l}\text { Independence } \\
\text { (INDP }\end{array}$ & 14,00 & 15,58 & 7,00 & 10,00 & 20,00 & 20,00 & 3,04 & 2,17 \\
$\begin{array}{l}\text { Professionalism } \\
\left(\text { PROFS }_{i}\right)\end{array}$ & 85,09 & 90,01 & 58,00 & 75,00 & 106,00 & 108,00 & 8,33 & 6,50 \\
& & & & & & & & \\
\hline
\end{tabular}

\subsection{Hypothesis Testing Results}

Results of testing hypothesis 1 are presented in Table 2

Table 2

The result of Hypothesis Testing with-Independent Sample Test

\begin{tabular}{ccrc} 
Variable & Group & Mean & t-test (Sign) \\
& & & \\
\hline $\mathrm{SP}_{\mathrm{i}}$ & BIG 4 & 7,990 & \multirow{2}{*}{$1,408(0,161)$} \\
\hline
\end{tabular}


Table 2 shows that hypothesis 1 is not supported, it appears that there are no differences in average significant score of professional sanctions between auditors working in KAP big 4 and auditors working in KAP non big four, although the value of the average score of sanctions professionals on auditors working in KAP big 4 auditors are lower than in non big KAP 4. This means that the level of concern of getting professional sanctions from big 4 auditors at KAP is lower than non-big four accounting firm, but the differences were not significant.

\subsection{Hypothesis 2 and 3}

Results of testing hypotheses 2 and 3 are presented in Table 3 Table 3

Results of testing hypotheses 2 and 3Uji Regresi Berganda

\begin{tabular}{|c|c|c|c|c|c|}
\hline & & Coefficient score & Uji t (Sig.) & Adjusted $\mathbf{R}^{2}$ & F-test \\
\hline \multicolumn{6}{|c|}{ Model 1 without $\mathrm{SP}_{\mathrm{i}}$ dan $\mathrm{PROFS}_{\mathrm{i}}$ interaction } \\
\hline 1 & $\mathrm{SP}_{\mathrm{i}}$ & $0,408 * *$ & $3,312(0,001)$ & 0,26 & $22,644(0,000)$ \\
\hline 2 & $\mathrm{PROFS}_{\mathrm{i}}$ & $0,143 * *$ & $6,281(0,000)$ & & \\
\hline 3 & GENDER $_{\mathrm{i}}$ & $-0,137 *$ & $-2,145(0,033)$ & & \\
\hline \multicolumn{6}{|c|}{ Model 2 with $\mathrm{SP}_{\mathrm{i}}$ dan $\mathrm{PROFS}_{\mathrm{i}}$ interaction } \\
\hline 1 & $\mathrm{SP}_{\mathrm{i}}$ & $3,111 * *$ & $2,584(0,011)$ & 0,276 & $18,638(0,000)$ \\
\hline 2 & PROFS $_{\mathrm{i}}$ & $0,385 * *$ & $3,520(0,001)$ & & \\
\hline 3 & $\mathrm{SP}_{\mathrm{i}} * \mathrm{PROFS}_{\mathrm{i}}$ & $-0,030 *$ & $-2,257(0,25)$ & & \\
\hline 4 & GENDER $_{\mathrm{i}}$ & $-0,131 *$ & $-2,068(0,040)$ & & \\
\hline
\end{tabular}

Table 3 shows the results of multiple regression tests with two test models. The first model was used to compare with the second model to determine the moderating effects of variables concerns professional sanctions (SPi) on the relationship between professionalism (PROFSi) and independence (INDPi). SPi variables influence the test results and PROFSi individually against INDPi variable indicates that SPi and PROFSi variables significantly influence INDPi variables with a significance level below $1 \%$. This suggests that the second hypothesis is supported. In other words, the 
professional sanction concerns affect the auditor's independence. These test results support the social cognitive theory that the legal environment affects the formation of cognitive auditors indicated by the perception of the risk of getting professional sanctions. The higher the risk of getting sanction professionally, auditor increasingly aware will be sanctioned professionally so he will be cautious in giving an audit opinion or become more independent.

Table 3 shows that the adjusted R2 for the model without interaction is smaller than the model with interaction. This means that the variable interactions SPi * PROFSi an explanatory factor for INDPi. In other words, professional concerns sanctioned moderate the relationship between professionalism and auditor independence. However, the third hypothesis is not supported for interaction variables SPi * PROFSi coefficient is negative, which means that the variable SPi weaken the relationship PROFSi and INDPi. This means, when fear of professional sanctions became higher, it lessens the relationship between professionalism and auditor independence. Professional sanction concern is a factor that is a substitute for professionalism. When the auditor's professionalism is low but has high professional sanction concerns, the auditor can still act independently. The test results of the interaction effect SPi $*$ PROFSi provides evidence that when the auditor is not or less professional but being in an environment that is perceived by the auditor to have a high risk of getting penalized, the auditor did not dare to take action that threatens its independence.

\section{Conclusions, Implications and Limitations}

This study suggests that first, professional sanction concerns are not affected by the auditor's workplace. Although professional sanction concerns from big 4 auditors at KAP is lower than the auditor at KAP non-big four, the difference found was not significant. Second, professional sanction concerns and professionalism, has substitution characteristic, in influencing the independence of auditors. In other words, when one factor is low, then the auditor's independence can still be maintained. If the 
auditor does not behave professionally but has high professional sanction concerns, then he will keep its independence for fear of professional sanctions.

The implication of this study is the importance of law enforcement in improving the performance of auditors. Auditor with the big four and non-big four proven equally have professional sanction concerns and the higher professional sanction concerns, the higher the auditor's independence. If the rules are implemented effectively on both auditors with a high level of professionalism, medium or low professionalism auditors would be afraid to meet the wishes of clients (audited) that could threaten its independence. The results provide an essential contribution to both government regulators and the Committee for Public Accounting Profession to be serious in enforcing the rules that have been created.

Although the results of this study provide important policy implications, the results of this study cannot be separated from the weaknesses. First, the use of scenario-based survey methods has many drawbacks, especially regarding internal validity because researchers can not strictly control the process of filling out the questionnaire given to the subject. Second, the amount of data obtained from this study is not in proportion between different position level, because most of the questionnaires filled out by the junior and senior auditor. This is unavoidable because of the number of junior and senior auditors at each KAP are far more than the manager and partner. Also, to get a response from the partner or manager to be interested in filling the questionnaire is also very difficult because they do not have much free time to fill out a questionnaire that researchers submit to them.

\section{Reference}

Anggraini, F.R.R., Z. Baridwan; Suwardjono; and H. Basuki. 2013. Role of Work Context in the Effectiveness of Auditor Professionalism Development: Case in Indonesia. Working Paper.

Bandura, A. 2001. Social Cognitive Theory: An Agentic Perspective. Annual Review Psychology, 52:1-26. 
Clarkson, P. M., Emby, C., and V. W.-S. Watt. 2002. Debiasing the Outcome Effect: The Role of Instructions in an Audit Litigation Setting. Auditing: A Journal of Practice \& Theory, 21(2): 7-20.

Fan, J. P. H., and T. J. Wong 2005. Do External Auditors Perform a Corporate Governance Role in Emerging Markets? Evidence from East Asia. Journal of Accounting Research, Vol. 43(1): 35-72.

Fargher, N., M. H. Taylor, and D. T. Simon 2001. The demand for auditor reputation across international markets for audit services. The International Journal of Accounting, 36(4): 407-421.

Farmer, T.A., L.E. Rittenberg, and G.M. Trompeter. 1987. An Investigation of the Impact of Economic and Organizational Factors on Auditor Independence. Auditing: A Journal of Practice \& Theory, Vol. 7 (1): 1-14.

Favere-Marches, M. 2000. Audit Quality in ASEAN. The International Journal of Accounting 35 (1):121-149.

Francis, J.R. and D.Wang. 2008. The Joint Effect of Investor Protection and Big 4 Audits on Earnings Quality Around the World. Contemporary Accounting Research, Vol. 25 (1): 157-191.

Gendron, Y., R. Suddaby, and H. Lam. 2006. An Examination of the Ethical Commitment of Professional Accountants to Auditor Independence. Journal of Business Ethics, Vol. 64: $169-193$

Grant, J., R. Bricker, and R. Shiptsova. 1996. Audit Quality and Professional Self-Regulation: A Social Dilemma Perspective and Laboratory Investigation. Auditing: A Journal of Practice \& Theory, Vol. 15 (1): 142-156.

Jones, J., D. W. Massey, and L. Thorne. 2003. Auditors' Ethical Reasoning: Insights from Past Research and Implications for the Future. Journal of Accounting Literature 22:45103.

Khrishnan, J. and J. Krishnan. 1997. Litigation Risk and Auditor Resignations. The Accounting Review, Vol. 72 (4): 539-560

Khurana, I. K., and K. K. Raman. 2004. Litigation Risk and the Financial Reporting Credibility of Big 4 versus Non-Big 4 Audits: Evidence from Anglo-American Countries. Accounting Review 79 (2):473-495.

KNKG. 2006. Pedoman Umum Good Corporate Governance Indonesia. Komite Nasional Kebijakan Governance.

LaPorta, R., F. Lopez-De-Silanes, and A. Shleifer. 2006. What Works in Securities Laws? The Journal of Finance, Vol. 61 (1): 1-32 
Li, C. 2009. Does Client Importance Affect Auditor Independence at the Office Level? Empirical Evidence from Going-Concern Opinions. Contemporary Accounting Research, Vol. 26 (1): 201-230.

Lu, T. 2006. Does Opinion Shopping Impair Auditor Independence and Audit Quality? Journal of Accounting Research, 44(3): 561-583.

Lui, S.S., H. Ngo, and A.W.Tsang. 2003. Socialized to be a Professional: a Study of the Professionalism of Accountants in Hong Kong. International Journal of Human Resource Management, Vol. 14 (7): 1192-1205.

Melumad, N. D. and L. Thoman. 1990. On Auditors and the Courts in an Adverse Selection Setting. Journal of Accounting Research, Vol. 28 (1): 77-120.

Michas, P. N. 2011. The Importance of Audit Profession Development in Emerging Market Countries. Accounting Review 86 (5):1731-1764.

Moore, D. A., P. E. Tetlock, L. Tanlu, dan M. H. Bazerman. 2006. Conflicts of Interest and the Case of Auditor Independence: Moral Seduction and Strategic Issue Cycling. Academy of Management Review 31 (1):10-29.

NN. 2012. Ikatan Akuntan Indonesia: 55 Tahun Merentang Zaman. Akuntan Indonesia, Desember: 7-9.

Peraturan Pemerintah Nomor 84 Tahun 2012 tentang Komite Profesi Akuntan Publik.

Rama, D. V., and W. J. Read. 2006. Resignations by the Big 4 and the Market for Audit Services. Accounting Horizons, 20(2): 97-109.

Salancik, G.R. and J. Pfeffer. 1978. A Social Information Processing Approach to Job Attitudes and Task Design. Administrative Science Quarterly, Vol. 23: 224-253.

Siregar, B. 2006. Pemisahan Hak Aliran Kas dan Hak Kontrol dalam Struktur Kepemilikan Ultimat. Disertasi, Universitas Gadjah Mada. Tidak dipublikasikan.

Suddaby, R., Y. Gendron, and H. Lam. 2009. The organizational context of professionalism in accounting. Accounting, Organizations and Society 34 (3-4):409-427.

Undang-Undang Nomor 5 Tahun 2011 tentang Akuntan Publik.

Zeff, S.A. 2003. How the U.S. Accounting Profession Got Where It Is Today: Part I. Accounting Horizon, Vol. 17 (3): 189-205. 
The Indonesian Journal of Accounting Research - Jan, Vol. 20, No.2 , 2017

Intentionally Blank 